\title{
Maksimalisasi Kualitas Belajar Peserta Didik Menggunakan Metode Learning By Doing Pragmatisme By John Dewey
}

\author{
Yugga Tri Surahman ${ }^{1}$ \& Endang Fauziati $^{2}$
}

Prodi Magister Pendidikan Dasar, Universitas Muhammadiyah Surakarta, Indonesia

${ }^{\square}$ E-mail: yuggatrisurahman10@gmail.com

\begin{abstract}
Abstrak
Memaksimalkan kualitas belajar peserta didik dengan menggunakan metode Learning By Doing. Tujuan penelitian ini adalah uintuk mengetahui metode Learning By Doing. model pembelajaran learning by doing artinya sebuah konsep belajar menggunakan melakukan serta mengerjakan secara aktif, yaitu sebuah pandangan pendidikan pragmatisme berdasarkan dua alasan krusial: yang pertama adalah suatu takdir Tuhan bahwa anak merupakan makhluk ciptaan yang aktif aktif, yang kedua adalah melalui bekerja anak by doing yaitu bahwa siswa perlu terlibat dalam proses belajar secara impulsive/spontan. Dalam hal ini akan membantu peserta didik untuk menumbuhkan kemampuan belajar aktif pada proses pembelajaran. Penelitian yang akan digunakan adalah jenis penelitian kualitatif. Desain rancangan penelitian disusun oleh peneliti menggunakan Kajian Literatur. harapan dari Literatur ini bisa memaksmalkan kualitas belajar melalui metode Learning By Doing pada Sekolah. Hasil dari metode ini adalah peserta didik mampu merangsang dan bersungguh-sungguh dalam proses belajar mengajar sehingga keaktifan peserta didik dapat maksimal dan target tercapai sesuai harapan.
\end{abstract}

Kata Kunci: John Dewey; Learning by Doing; Pragmatisme.

\begin{abstract}
Maximizing the quality of student learning by using the Learning By Doing method. The purpose of this study was to determine the method of Learning By Doing. The learning by doing model means a concept of learning by doing and doing actively, which is an educational view of pragmatism based on two crucial causes: the first is God's destiny that children are active creations, the second is that children work by doing it. students need to be involved in the learning process impulsively / spontaneously. In this case it will help students to grow active learning skills in the learning process. The research that will be used is a qualitative research type. The research design was prepared by the researcher using Literature Review. It is hoped that this literature can maximize the quality of learning through the Learning By Doing method at the school. The result of this method is that students are able to stimulate and be serious in the teaching and learning process so that student activity can be maximized and the target is achieved as expected.
\end{abstract}

Keywords: John Dewey; Learning by Doing; Pragmatism. 


\section{PENDAHULUAN}

Pendidikan adalah sebuah hal terpenting dalam kehidupan khususnya bagi generasi penerus bangsa ini yaitu peserta didik. kesadaran akan pentingnya sebuah pendidikan pun sangat dibutuhkan agar menjadi upaya meningkatkan kualitas sumber daya insan/manusia itu sendiri. Dana Ratifi Suardi (2012) mengatakan bahwa dengan adanya proses belajar mengajar dengan sistem yang cukup baik, maka pendidikan telah terselenggara/diadakan dengan sangat baik. Serta menurut Hamalik (pada Dana Ratifi Suardi, 2012) pedagogi/pembelajaran menjadi suatu sebuah sistem, artinya suatu totalitas yang terarah dan terfokus pada tujuan itu sendiri.

Pragmatisme merupakan sebagai pendekatan terhadap sebuah masalah dalam hidup nyata dan secara praktis, bukan secara teoritis / ideal, alhasilnya bisa dimanfaatkan, dan langsung dapat berhubungan dengan sebuah tindakan, bukan spekulasi atau abstraksi semata.(Yuliani, 2018).

Pada pengajaran ada beberapa komponen terpenting, yaitu guru atau pengajar, siswa, metode atau media, perlengkapan pembelajaran, dan lingkungan kelas yang terarah dalam pencapaian tujuan pembelajaran itu sendiri.(Ord, 2012).

Pengembangan serta peningkatan sumber daya insan/manusia itu melalui pembelajaran yang efektif akan membantu meningkatkan keberhasilan proses belajarmengajar yang bisa membawa pada situasi pembelajaran yang aktif dan efektif atau dua arah. ada beberapa faktor yang menghipnotis kualitas dan hasil belajar peserta didik itu sendiri, yaitu faktor ekstern serta intern. Faktor ekstern ialah faktor yang berasal dari luar diri individu, sedangkan intern asal berasal dalam diri individu itu sendiri. contoh berasal factor ekstern diantaranya: (a) Faktor keluarga/family, (b) Faktor sekolah, (c) Faktor warga/masyarakat . model faktor intern yaitu: (a) Faktor jasmaniah, (b) Faktor psikologis, (c) Keaktifan siswa pada bermasyarakat (Dana Ratifi Suardi, 2012). Sedangkan Budi Kurniawan, dkk (2017) menjelaskan contoh faktor ekstern diantaranya: (a) Metode mengajar, (b) Media pembelajaran, (c) hubungan siswa dengan lingkungan sosial, (d) Proses belajarmengajar. model dari faktor intern yaitu minat individu itu sendiri serta juga motivasinya.

Tatan dan Teti (dalam indah Lestari, 2020), berpandangan bahwa "Belajar selalu melibatkan perubahan dalam diri individu seperti kematangan berpikir, berperilaku juga kedewasaan pada menentukan keputusan serta pilihan"..dari Sudjana (dalam indah Lestari, 2020), "hasil belajar ialah kemampuan yang dimiliki peserta didik setelah mereka mendapatkan pengalaman belajarnya". Sedangkan dari Nasution (dalam indah Lestari, 2020) menyatakan bahwa hasil belajar adalah suatu perubahan yang terjadi pada individu yang belajar, bukan saja perubahan tentang pengetahuan, namun juga buat menghasilkan kecakapan dan penghargaan dalam diri pribadi saat belajar.

Hasil belajar merupakan dampak dari proses belajar seorang. hasil belajar terkait dengan perubahan pada diri seseorang yang mau belajar. Bentuk perubahannya berupa perubahan pengetahuan, pemahaman, sikap serta tingkah laku, keterampilan dan kecakapan. Perubahan dalam arti adalah perubahan-perubahan yang ditimbulkan oleh pertumbuhan tak diklaim sebagai akibat belajar. Perubahan sebagai hasil belajar bersifat relatif menetap dan mempunyai potensi untuk dapat mengembangkan apa yang telah didapat/dipelajari saat menuntuk ilmu baik secara formal maupun secara non 
formal.dimana pengetahuan akan terus bertambah jika terus di asah dan digali.

Kurikulum yang dipergunakan saat ini yaitu kurikulum 2013, dimana menerapkan sistem merdeka belajar. Disini, peserta didik dituntut untuk aktif dalam segala bidang di antaranya bertanya, mencari, menyelidiki bahan ajar yang diperoleh. Perlu adanya metode pembelajaran yang efektif sehingga peserta didik bisa tahu, menangkap serta menyerap semua bahan ajar yang diberikan sang pengajar atau pengajar secara maksimal. misalnya saja menggunakan metode Learning By Doing (LBD).(Silaban \& Mauliadi, 2019).

Penerapan Kurikulum 2013 ini juga menitik beratkan kepada pembelajaran yang mengaplikasikan dan mengkaitkan konsep belajar menggunakan (objek) konkret yang terjadi serta dialami dan ada di sekitar peserta didik dalam kehidupan sehari-hari. Hal ini ditimbulkan karena, dengan pengaplikasian strategi kontekstual pada pada pembelajaran peserta didik diposisikan dan dibiasakan untuk dapat terlibat secara aktif serta mandiri pada aktivitas belajar mengajar dengan mengkombinasikan konsep pembelajaran melalui hal-hal yang terdapat serta tidak jarang dicermati dan diamati oleh peserta didik pada lingkungannya dengan pengetahuan yang ada pada di dirinya. (Engkoswara. 2002).

Apabila cara dan konsep tersebut bisa terlaksana dengan baik, maka proses pembelajaran yang dilakukan oleh guru serta peserta didik akan lebih bermakna dan menyenangkan (Nababan dan Matondang, 2015, p. 187 pada Rospita \& Mauliadi, 2019) Pembelajaran dengan menggunakan berbagai hal yang ada pada sekitar peserta didik dan tak jarang dimainkan (kontekstual) secara tidak langsung akan membentuk pembelajaran yang bermakna dan menyenangkan. sebagai akibatnya, tujuan pembelajaran yang diharapkan akan dengan praktis tercapai.(Hasruddin et al., 2015).

Penerapan pembelajaran menggunakan orientasi kontekstual berbasis etnomatematika menurut peneliti menjadi sebuah treatment yang bisa ditempuh oleh pengajar buat menjadikan konsep pembelajaran learning by doing yang mengikutsertakan seluruh panca indera di dalam proses belajar mengajar. Metode Learning By Doing lebih menekankan pada peran aktif peserta didik supaya dapat mengalami sendiri info tentang bahan ajar yang disampaikan oleh gur/pengajar sehingga peserta didik bisa melihat dan praktik secara eksklusif selama proses pembelajaran berlangsung (Reni Herniati, dkk, 2017). Tujuan penelitian ini buat mengetahui keefektifan metode learning by doing dalam memaksimalkan kualitas belajar peserta didik.

\section{METODE PENELITIAN}

Jenis penelitian yang digunakan merupakan penelitian Kualitatif. menurut Denzin \& Lincolin,1994 dalam Anggito dan Setiawan, 2018:7 menyatakan bahwa penelitian kualitatif merupakan penelitian yang memakai latar alamiah menggunakan maksud menafsirkan fenomena yang terjadi dan dilakukan dengan jalan melibatkan berbagai metode yang ada. Sedangkan dari Krik \& Miller, 1986: 9 dalam Anggito serta Setiawan, 2018: 7-8 mendefinisikan bahwa penelitian kualitatif merupakan tradisi eksklusif pada ilmu pengetahuan sosial yang secara mendasar bergantung dari pengamatan pada manusia baik dalam kawasannya maupun dalam peristilahannya. Desain rancangan penelitian disusun oleh peneliti menggunakan kajian literatur jurnal penelitian.(Mata et al., n.d.) 
Metode Penelitan ini dilakukan pada Sekolah Dasar Negeri Mansaburi Kampung Wariori Distrik Masni Kabupatem Manokwari Papua Barat. Penelitian ini dilakukan dalam bentuk observasi, wawancara pada sekolah dengan melakukan kegiatan langsung sesuai mata pelajaran yang di ajarkan masing-masing sehingga peneliti bisa melihat secara langsung pelaksanaan Learning By doing. Penelitian melakukannya pada Peserta didik kelas VI dimana berjumlah 25 Peserta Didik.

\section{HASIL DAN PEMBAHASAN}

Pembelajaran ialah sebuah proses interaksi antar peserta didik, antara peserta didik dan pendidik, serta antara peserta dan sumber belajar lainnya di suatu lingkungan belajar yang berlangsung secara edukatif, supaya peserta didik bisa membentuk perilaku, pengetahuan serta keterampilannya untuk mencapai tujuan yg telah ditetapkan. Proses pembelajaran merupakan suatu proses yang mengandung serangkaian aktivitas mulai asal perencanaan, pelaksanaan hingga penilaian.

Dalam sebuah kitab Muqaddimah, Ibn Khaldūn menjelaskan bahwa sebuah ilmu pengetahuan dan pendidikan smerupakan sebuah kebutuhan yang sangat mendasar dan sangat dibutuhkan oleh manusia didalam tengah - tengah peradaban sekarang. Menurutnya pendidkan memilik partian yang luas. Pendidikan tidak hanya sebuah proses belajar mengajar yang dibatasi oleh ruang dan waktu, tetapi pendidikan merupakan sebuah proses manusia secara sadar dalam menangkap, menyerap dan menghayati peristiwa-peristiwa alam sepanjang hidupnya.(T. Saiful Akbar, 2015).

Keterkaitan Faktor-faktor adala sebuah penentu tersebut dimana satu kesatuan yang tidak bisa dipisahkan. Peran aktif guru/pendidi adalah tetap konsisten dan komitmen dalam mempertimbangkan faktor eksternal (diluar dari guru), faktor internal (dalam diri guru), dengan demikian teknikteknik pembelajaran efektif dan efisien dapat dilaksanakan dengan baik disekolah, (Widiyati, 2020).

Pendidik berusaha agar peserta didik mampu ikut berpartisipasi aktif dalam mengembangkan kegiatan fisik dan berbagai macam banyak gerakan atau aktifitas. Dengan demikian peserta didikdapat mengikuti sebuah proses pendidikan dan mengembangkan meningkatkan minatnya.

Usaha dalam memunculkan sebuah minat dalam hal berintelektual adalah dapat menyelesaiakan sebuah permasalahan, dan dapat menemukan ide atau hal yang baru serta menggambarkan atau menjelaskan sesuatu hal yang sifatnya berlangsung, sehingg minat yang bersifat sosial tetap terdapat dalam hubungan interpersonal peserta didik.(Khaerul Anwar, 2016).

Upaya dalam menumbuhkan dan meningkatkan motivasi dalam belajar peserta didik juga bisa dilakukan dengan membuat bahan ajar secara bisa menarik peserta didik. Motivasi mempunyai hubungan yang erat terhadap emosi, kemauan dan keinginan peserta didik. Motivasi intrinsik merupakan sebuah dorongan rasa ingin mengetahui, keinginan dan kemauan mencoba serta sikap mandiri peserta didik dapat dijadikan sebuah landasan bagi para pendidik/guru untuk mendaptkan sebuah pola motivasi yang bersifat ekstrinsik, sehingga tujuan pembelajaran efektif. Dan efisiensy. (Rosidah, 2018).

Pendidikan peserta didik tidak bisa lepas dari kiprah/peran serta seorang guru, karena seorang guru adalah orang yang akan membimbing dan mengarahkan dan mengevaluasi hasil belajar peserta didik, 
sebab pendidikan itu sendiri adalah sebuah bimbingan serta pengarahan. Hal itu sesuai apa yg dikatakan oleh John Dewey (melalui Priyanto, 2017) "The word education means just process of leading or bringing up", Arti istilah pendidikan adalah proses bimbingan dan pengarahan.(Hasruddin et al., 2015).

Contoh pembelajaran learning by doing dipelopori oleh John Dewey. Konsep belajar melalui melakukan, menjadi asas seluruh pengajaran John Dewey dan pertama kali diterapkan berupa sekolah kerja yg di uji cobakan di AS di tahun 1859, yaitu suatu pandangan pendidikan pragmatisme sesuai dua alasan krusial, pertama, adalah suatu takdir Tuhan bahwa anak merupakan makhluk aktif (alasan psikologis); ke 2, melalui bekerja anak disiapkan buat kehidupan pada masa depan (Kurniawan et al., 2018).

Belajar aktif atau learning by doing artinya teori Dewey. Dewey merupakan pendiri Dewey School yang menerapkan prinsip-prinsip learning by doing, yaitu bahwa peserta didik perlu terlibat pada proses belajar secara spontan. berasal rasa keingintahuan siswa akan hal-hal yang belum diketahuinya mendorong keterlibatannya secara aktif pada suatu proses belajar.

Belajar aktif mengandung banyak sekali kiat yang berguna untuk menumbuhkan kemampuan belajar aktif pada diri peserta didik serta menggali potensi peserta didik serta pengajar untuk sama-sama berkembang dan membuatkan pengetahuan, keterampilan, serta pengalaman. peran serta peserta didik dan pengajar pada konteks belajar aktif sebagai sangat krusial. guru berperan aktif menjadi fasilitator yang membantu memudahkan peserta didik belajar, menjadi narasumber yang bisa mengundang pemikiran dan daya kreasi siswa, menjadi pengelola yang mampu mengundang pemikiran serta daya kreasi siswa, menjadi pengelola yg bisa merancang dan melaksanakan aktivitas belajar bermakna serta bisa mengelola sumber belajar yang diperlukan.(Hadinatha, 2018).

Peserta didik pula terlibat pada proses belajar beserta guru karena peserta didik dibimbing, diajar serta dilatih menjelajah, mencari, mempertanyakan sesuatu menyelidiki jawaban atas suatu pertanyaan, mengelola serta memberikan yang akan terjadi perolehannya secara komunikatif.

Selain itu, peserta didik dibina untuk dapat mempunyai keterampilan supaya bisa menerapkan dan memanfaatkan pengetahuan yang pernah diterimanya dalam hal-hal atau persoalan yang baru dihadapi. dengan demikian peserta didik bisa belajar mandiri, belajar aktif, pada dasarnya berusaha buat memperkuat dan memperlancar stimulus yang diberikan guru serta respons anak didik dalam pembelajaran, sebagai akibatnya proses pembelajaran menjadi suatu hal yang menyenangkan tidak sebagai hal yang membosankan bagi mereka.(muhammad kristiawan, 2016).

Pembelajaran dengan learning by doing direncanakan dengan mengatur ketika serta tempat secara spesifik buat tiap kompetensi. Pembelajaran ditekankan di drill, riview, demontrasi dan pembelajaran yang sistematis untuk menyampaikan pengalaman belajar kepada peserta didik sinkron dengan situasi dan syarat pada global kerja. Pendekatan pembelajaran ini lebih menyebarkan akibat yang nyata serta kecakapan. (Nasution, 2017).

Pembelajaran learning by doing memiliki fungsi sebagai berikut;

Pertama, memperkenalkan beberapa realita dalan pengajaran, yakni; (a) membuatkan materi pembelajaran asal empiris kurang lebih, tidak hanya asal apa yg 
terdapat di kitab; dan (b) mengundang praktisi ke dalam kelas untuk menambah wawasan siswa dalam rangka melengkapi penjelasan pengajar baik secara teori maupun praktek(Robani et al., 2021).

Kedua, melaksanakan serangkaian pengajaran langsung dengan melibatkan peserta didik untuk memecahkan masalah menggunakan bimbingan guru, yaitu: (a) memperhatikan kebebasan akademik guna menyebarkan prinsip berdasarkan perilaku saling menghormati dan memperhatikan satu sama lain (antara pengajar dan pesert didik, dan antara siswa dan siswa lainnya); dan (b) memberikan kesempatan pada peserta didik untuk aktif berpartisipasi pada merencanakan kegiatan, melakukan proses serta pengambilan keputusan.

Aktifitas pembelajaran bekerja langsung artinya pendekatan interaktif edukatif yang sangat efektif, sebab peserta didik melakukan demontrasi serta eksperimen menggunakan mencoba mengerjakan sesuatu dan mengamati proses serta akibat uji coba. Demontrasi dan eksperimen dalam pembelajaran learning by doing dilaksanakan menggunakan tujuan menjadi berikut: (a) buat mengetahui sesuatu secara lebih absolut dan teliti; (b) melakukan pengamatan dan pengumpulan data; (c) melaksanakan percobaan sinkron menggunakan prinsip learning by doing, bahwa teori yang telah dipelajari harus ditindaklanjuti menggunakan perbuatan; serta (d) Menganalisa produk untuk memperoleh hasil yang optimal.

Dalam pembelajaran learning by doing terdapat prinsip-prinsip yang wajib dipertimbangkan dalam pembelajaran.

Pertama, melibatkan peserta didik secara pribadi pada aktivitas belajar mengajar, sebab pendekatan ini menekankan pada pengalaman peserta didik secara langsung yang berkenaan menggunakan kompetensi yang harus dikuasai.

kedua, menyediakan pendekatan multi sensori bagi peserta didik ketika berlangsung pembelajaran, seperti mendengar, merasa, mencium, dan mencipta objek-objek yang dipelajari.

Ketiga, menyampaikan kompetensi bagi peserta didik untuk berbagi keterampilan menggunakan material dan melakukan eksperimen.

Keempat, membina suasana sosial yg transaksional antara siswa dan guru. Keterlibatan peserta didik pada pembelajaran learning by doing tak hanya sebatas fisik semata, tetapi lebih dari itu terutama adalah keterlibatan mental emosional, keterlibatan dengan kegiatan kognitif pada pencapaian dan perolehan pengetahuan, penghayatan serta internalisasi nilai-nilai pada pembentukan perilaku serta nilai, dan juga pada saat mengadakan latihan-latihan pada pembentukan keterampilan. Adapun bentukbentuk pengajaran pada konteks learning by doing, pada antaranya adalah sebagai berikut (Djamarah, 2002: 223-225).

Pertama, Menumbuhkan motivasi belajar peserta didik dengan cara mendorong rasa ingin tahu, asa mencoba, serta sikap berdikari anak didik. mampu juga dengan memberikan motivasi ekstrinsik yaitu dengan menyampaikan rangsangan berupa anugerah nilai tinggi atau hadiah bagi peserta didik berprestasi dansebaliknya.

kedua, mengajak siswa beraktivitas. Bentuk pelaksanaanya ialah mengajak anak didik melakukan kegiatan atau bekerja di laboratorium, di lapangan menjadi bagian dari eksplorasi pengalaman, atau mengalami pengalaman yg sama sekali masih baru.

Ketiga, mengajar dengan memperhatikan disparitas individual. Proses aktivitas belajar mengajar dilakukan 
menggunakan syarat masing-masing peserta didik sebab tidak semua peserta didik itu sama kemampuannya. Terdapat beberapa faktor penyebab anak mempunyai akibat belajar buruk, diantaranya; faktor kesehatan, kesempatan belajar di rumah tidak terdapat, sarana belajar kurang, dan sebagainya.

Keempat, mengajar menggunakan umpan balik: Bentuknya antara lain umpan kemampuan perilaku peserta didik (perubahan tingkah laku yg bisa ditinjau anak didik lainnya, pendidik atau siswa itu sendiri), umpan balik perihal daya serap menjadi pelajaran untuk diterapkan secara aktif.

Kelima, mengajar dengan pengalihan, yaitu pengajaran yang mengalihkan (transfer) yang akan terjadi belajar pada situasi-situasi nyata yg bukan hanya bersifat ceramah atau diskusi, namun mengedepankan situasi nyata.

Keenam, penyusunan pemahaman yang logis dan psikologis. pedagogi dilakukan dengan memilih metode yang proporsional, baik dengan metode ceramah maupun metode pemberian tugas pada siswa. Hal ini dilakukan sinkron menggunakan syarat materi pelajaran.

Model pembelajaran seperti ini membuat peserta didik dapat lebih paham dan bukan hanya sekedar tahu atau hafal, siswa atau peserta didik diajak untuk melakukan, melihat, mendengar, merasakan secara langsung objek yang sedang dipelajari, dengan kata lain mempraktekkannya, sehingga siswa memahaminya sampai pada tingkat yang sebenar-benarnya dan memahami isi materi tersebut.(Dewey et al., n.d.).

\section{KESIMPULAN}

Melalui metode Learning By Doing peserta didik akan membantu untuk menumbuhkan kemampuan belajar aktif dalam proses pembelajaran. Metode ini terbukti sangat efektif dalam proses pembelajaran peserta didik. Hal ini tebukti dari beberapa kajian literatur yang sudah dirangkum, yang menyebutkan bahwa Metode Learning By Doing sangat efektif dalam menaikkan hasil belajar atau prestasi peserta didik. Dalam masa pandemi saat ini, keseriusan peserta didik dalam menerapkan metode LBD sangat diharapkan campur tangan wali siswa juga sangat dibutuhkan guna mengawasi dan mendampingi siswa selama belajar pada tempat tinggal .

Peneliti berharap metode LBD terus tetap dilaksanakan sehingga peserta didik tetap berkomitmen untuk terus berkarya dalam membuat hal-hal yang creative dan dapat mencapai tujuan pendidikan tersebut.

\section{DAFTAR RUJUKAN}

Dewey, D. A. N. J., Ricky, R., \& Wiranata, S. (n.d.). Prodi Manajemen Dakwah STAI Terpadu Yogyakarta.

Hadinatha, M. F. (2018). Jejak Pragmatisme dalam Politik di Indonesia (Era 2009 2017). Kalimah, 16(2). https://doi.org/10.21111/klm.v16i2.287 2

Hasruddin, H., Nasution, M. Y., \& Rezeki, S. (2015). Inovasi pembelajaran dengan penerapan pembelajaran kontekstual untuk meningkatkan kecakapan sosial mahasiswa pada perkuliahan strategi belajar mengajar biologi. Prosiding Semirata 2015 Bidang MIPA BKS-PTN Barat, 47-56.

Khaerul Anwar. (2016). Mimbar Kampus METODE CONTEXTUAL TEACHING AND LEARNING Mimbar Kampus. 51-68.

Kurniawan, B., Wiharna, O., \& Permana, T. (2018). Studi Analisis Faktor-Faktor yang Mempengaruhi Hasil Belajar pada Mata Pelajaran Teknik Listrik Dasar Otomotif. Journal of Mechanical Engineering Education, 4(2), 156. https://doi.org/10.17509/jmee.v4i2.962 
7

Mata, D., Linguistik, K., Komparatif, H., \& His-, L. H. K. (n.d.). Penerapan metode. 1, 159-167.

muhammad kristiawan. (2016). Filsafat 2016.

Nasution, M. K. (2017). Penggunaan metode pembelajaran dalam peningkatan hasil belajar siswa. STUDIA DIDAKTIKA: Jurnal Ilmiah Bidang Pendidikan, 11(1), 9-16.

Ord, J. (2012). John Dewey and Experiential Learning: Developing the theory of youth work. Youth \& Policy, 108, 5572. http://www.amazon.co.uk/YouthWork-Process-ProductPractice/dp/1905541112

Robani, M. E., Rachim, F. A., Febriani, A., \& A, E. R. F. (2021). Metode Learning By Doing Dalam Mengoptilalisasi Kualitas Belajar Siswa Smp. Jurnal Ilmiah Edukasia, 1(1), 24-30. https://doi.org/10.26877/jie.v1i1.7961

Rosidah, R. (2018). Menumbuhkan Motivasi Belajar Anak Sekolah Dasar Melalui Strategi Pembelajaran Aktif Learning By Doing. Qawwam, 12(1), 1-17. https://doi.org/10.20414/qawwam.v12i
1.748

Silaban, R., \& Mauliadi. (2019). Kajian Mengenai Pentingnya Implementasi Pembelajaran Dengan Orientasi Kontekstual Berbasis Etnomatematika. Seminar Nasional Pendidikan Dasar Universitas Negeri Medan, I S B N 9 7 8-602-53076-1-4, 240-245.

T. Saiful Akbar. (2015). Manusia Dan Pendidikan Menurut Pemikiran Ibn Khaldun dan John Dewey. Jurnal Ilmiah Didaktika, 15(2), 222-243.

Widiyati, T. (2020). Meningkatkan Prestasi Belajar Seni Rupa Materi Seni Rupa Murni Dengan Menerapkan Model Pembelajaran Learning By Doing Pada Siswa Kelas IX.8 SMP Neger 1 Praya Tahun Pelajaran 2017/2018. JISIP (Jurnal Ilmu Sosial Dan Pendidikan), 4(1), 142-155. https://doi.org/10.36312/jisip.v4i1.1035

Yuliani, Y. (2018). KONSEP PENDIDIKAN ISLAM DAN BARAT (Analisis Komparatif Pemikiran Imam azZarnuji dan John Dewey). Rausyan Fikr: Jurnal Pemikiran Dan Pencerahan, 14(02), 1-16. https://doi.org/10.31000/rf.v14i02.897 